\title{
Synthesis and study on biological activity of nitrogen-containing heterocyclic compounds - regulators of enzymes of nucleic acid biosynthesis
}

\author{
I. V. Alexeeva, A. D. Shved \\ Institute of Molecular Biology and Genetics, NAS of Ukraine \\ 150, Akademika Zabolotnogo Str., Kyiv, Ukraine, 03680 \\ i.v.alexeeva@imbg.org.ua
}

\begin{abstract}
Results of investigations on the development of new regulators of functional activity of nucleic acid biosynthesis enzymes based on polycyclic nitrogen-containing heterosystems are summarized. Computer design and molecular docking in the catalytic site of target enzyme (T7pol) allowed to perform the directed optimization of basic structures. Several series of compounds were obtained and efficient inhibitors of herpes family (simple herpes virus type 2, Epstein-Barr virus), influenza A and hepatitis $C$ viruses were identified, as well as compounds with potent antitumor, antibacterial and antifungal activity. It was established that the use of model test systems based on enzymes participating in nucleic acids synthesis is a promising approach to the primary screening of potential inhibitors in vitro.
\end{abstract}

Keywords: 6-azacytidine, as-triazinic nucleosides, acridones, phenazines, benzimidazothiazolones, inhibitors.

The Department of Synthetic Bioregulators (initially headed by A. D. Shved, PhD, and since 2009 - by I. Ya. Dubey) was established in 1998 via integration of two laboratories of IMBG to consolidate the scientific efforts of specialists in the fields of chemistry and biology, directed at elaborating synthetic inhibitors and using them in molecular and biological, biochemical and medical investigations.

The initial stage of the department work was logical continuation of previous scientific investigations on the chemical synthesis of antiviral and antitumor preparations on the basis of antisense-ribozyme approach to the control and inhibition of viral infections. By that time about 200 derivatives of triazine bases, $\mathrm{N}$-glycosides, differing in sugar content, and hybrid compounds (Figure, structures 1-3) were synthesized and studied.

The research work «Elaboration of a new antiviral and anti-mycoplasmal preparation on the basis of substance 6-azacytidine» (1997-2000) was successfully

(C) Institute of Molecular Biology and Genetics, NAS of Ukraine, 2013 performed due to creative collaboration with laboratories of several institutes of NAS and NAMS of Ukraine. 300 gram of 6-azacytidine were obtained in IMBG with experimental facilities by the elaborated technology. We carried out toxic-pharmacological investigations of the synthesized preparation, elaborated analytical and normative documents for the substance and pharmaceutical form as well as the pilot manufacturing instructions for the substance production and technological instruction for obtaining sterile injectable preparation of 6-azacytidine (6-AC, $\mathbf{1})$.

The independent testing on virus-cell models and laboratory animals allowed determining significant inhibitory activity of the substance and the elaborated injectable pharmaceutical form of 6-azacytidine against adenoviral, herpetic and mycoplasmal infections [1-5]. For instance, Zarubayev et al. (Research Institute of Influenza, RAMS) discovered a therapeutic effect of the preparation during experimental systemic adenoviral infection of newborn hamsters [2]. In 2011 the same authors demonstrated that compared to the novel Russian 


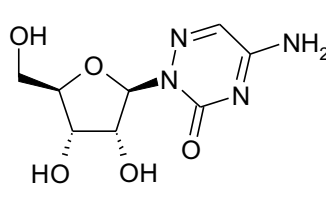

1<smiles>[R]NC(=O)c1cccc2nc3cccc([R])c3nc12</smiles>

4<smiles>O=C(NCCNc1cn[nH]c(=O)n1)c1cccc2nc3ccccc3nc12</smiles>

2<smiles>[R]NC(=O)CCc1n[nH]c(=O)[nH]c1=O</smiles>

3

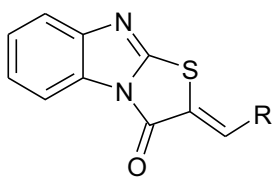

7
General structures of obtained compounds: $\mathrm{R}=\mathrm{Ar}$, Het; R'= H, Alk, Cl; R" = H, Rib, Xyl, Rha; $n=0,1$ preparation Ingavirin, the antiviral activity of 6-azacytidine in experiments with animals was higher by a factor of ten [3].

The laboratory testing of the pharmaceutical form 6-AC, performed by Prof. S. L. Rybalko in the L. V. Gromashevsky Institute of Epidemiology and Infectious Diseases, using the model of herpetic meningoencephalitis in mice, demonstrated reliable and highly efficient curative and prophylactic effect of the preparation and its low toxicity $[4,5]$. Besides, the antimycoplasmal effect of the preparation was proven on the model of bronchopneumonia of mice while infecting $\mathrm{Myco}$ plasma hominis (A. V. Rudenko, Urology Institute of NAMS of Ukraine), the ability of 6-azacytidine to induce the synthesis of interferon and to stimulate the functional activity of T- and B-lymphocytes was revealed in vitro and in vivo experiments [6].

Taking into account the absence of a licensed antiadenoviral preparations on the world market, the data received testify to the feasibility of further clinical trials of 6-azacytidine as a potential medical preparation.

In 2001 the Department of Synthetic Bioregulators developed and patented the new approach to the synthesis of triazine nucleosides on the basis of the simplified one-pot version of «silyl condensation» method. The suggested convenient approach secured a high yield of target products, and ensured the possibility of obtaining both 6-azacytidine and its different derivatives and $\mathrm{N}$ glycoside analogues, following the simplified scheme of nucleoside synthesis [7, 8].

A more complex approach was used for the synthesis of dideoxyderivatives of 6-azacytidine $i . e$. the trans- formation of yielded ribonucleoside using chemical methods with haloid-containing phosphonium reagent; also the mechanism of consecutive transformation of initial compounds into corresponding deoxyderivatives was determined. We established that during deoxygenation of 5'-O-benzoyl-6-azacytidine the intermediate compound is 2',3'-epoxy-derivative of 6-azacytidine instead of 2', $\mathrm{O}_{2}$-cyclonucleoside, as observed in the reaction with pyrimidine nucleosides. The following development of the epoxide cycle under the impact of the abovementioned reagents resulted in the formation of 2',3'-dihaloid-2',3'-dideoxy-6-azacytidine or nucleoside analogue with non-saturated bond in the carbohydrate fragment - 2',3'-didehydro-2',3'-dideoxy-6-azacytidine [9].

Further search for more active anti-adenoviral compounds among synthesized analogues and derivatives of 6-AC was performed by analyzing the structure-activity relationship of these compounds. The Quantitative Structure-Activity Relationship (QSAR) method was used to determine separate molecular fragments, enhancing the antiadenoviral activity [10]. High activity of 6azacytidine analogues, determined by QSAR method, correlates rather efficiently with that, experimentally obtained for new compounds: 2'-deoxy-, 2',3'-dideoxy- and $2^{\prime}, 3^{\prime}$-epoxy-derivatives of 6-AC, its acyclic and xylofuranose analogues $[8,11,12]$.

The PM3 method was used to perform semi-empirical quantum-chemical calculations of 6-AC, while the ab initio method was applied for non-empirical calculations on the level of theory MP2 $6-311++\mathrm{G}(3 \mathrm{df}$, 3pd) // MP2-6-311++G(d,p). We determined five most 
beneficial energy-wise structures of azanucleoside with different conformations of ribose fragment and orientation of heterocyclic base in the range of relative energies of $0-3.7 \mathrm{kcal} / \mathrm{mol}$ [13]. In our opinion, the location of 6-AC in syn-conformation results in a steric hindrance to its metabolic transformations (for instance, 5'O-phosphorylation), which are the basis of the effect of modified nucleosides. However, as proven by the obtained results, each selected 6-AC conformation may be the candidate for biologically active «working» conformation depending on the target.

The capability of 1,2,4-triazine derivatives to play the role of «universal base», capable of forming strong complexes with canonic Thy, Ade, Cyt, Gua, prompted us to perform triazine-based synthesis of the hybrid compounds with phenazine-1-carboxylic acid (PCA-1; 2) - non-nucleoside inhibitors [14]. At the same time, taking into account pharmacophoric properties of carboxamide group, we developed convenient methods of obtaining the series of $\mathrm{N}$-substituted amides of triazinyl-6-propanecarboxylic acid (PCA; 3) [15, 16] and $\mathrm{N}$-arylamides of PCA-1 (4) [17].

The system simulating the transcription, based on DNA-dependent RNA-polymerase of bacteriophage T7 (T7pol), was adapted for accelerated testing new compounds for biological activity [15-19]. The advantages of this model are its availability, synthesis productivity, plain quantitative determination of results, the possibility of simultaneous testing of dozens of substances in different variants of experiments and estimation of the affinity of compounds to DNA-matrix, the enzyme or to the transcriptional complex. Following the results of testing in the transcription system in vitro we revealed a number of carboxamides, inhibiting RNA synthesis at the concentration of $25 \mu \mathrm{g} / \mathrm{ml}$.

The application of this system allowed extending the library of compounds of this chemotype at the expense of N-hetarylamides PCA- 1 and 9-methylPCA-1 and N-arylamides of acridone- 4-carboxylic acid (ACA-4; 5). After the screening in T7 pol system the samples of compounds - efficient transcription inhibitors - were investigated for the antibacterial, antifungal, antituberculosis and antiviral activity. Among three dozens of investigated PCA amides there were three compounds, the antifungal activity of which regarding the strains of Candida albicans was higher than that of the well-known medical preparation diflucan (fluconazole) [15].

21 compounds from the series of $\mathrm{N}$-arylamides of PCA-1 demonstrated antituberculosis activity regarding the wild strain Mycobacterium tuberculosis with minimal inhibitory concentration (MIC) in the range of $0.5-$ $2.7 \mu \mathrm{M}, i . e$. at the level of the effect of isoniazid and rifampicin (MIC of 1.4 and $0.95 \mu \mathrm{M}$, respectively). Here some compounds were active against clinical isolates of M. tuberculosis with multiple resistance [17]. Considerable antibacterial activity regarding both grampositive and gram-negative bacteria was demonstrated by arylamides of both 9-substituted and non-substituted PCA-1 [18].

A series of $27 \mathrm{~N}$-arylamides of ACA-4 were studied in the testing of enzymatic systems of hepatitis $\mathrm{C}$ virus (HCV) replication in vitro on the basis of NS3-helicase of the virus and subgenome replicon of HCV. Five compounds demonstrated their ability of efficient $\left(\mathrm{EC}_{50}\right.$ 5.6-11.1 $\mu \mathrm{M}$ ) inhibition of helicase complex of $\mathrm{HCV}$ RNA-genome [19].

The department performed a considerable cycle of works [20-23] on the synthesis and investigation of derivatives of 3-oxo-1,2,4-triazine[5,6-b][1,4]benzothiazine (3-oxo-1,2,4-TBT; 6) - the structural analogues of triazine-containing polycyclic antibiotics. In part we changed the procedure of searching for potential inhibitors of T7pol using the molecular docking method and started computational investigation in determining the topology and tautomeric status of the main compound3-oxo-1,2,4-TBT. It was established that the structure of only one out of three most probable tautomers was close to the planar one, and it was the most advantegous energy-wise. According to the spectral data, this tautomer is formed during the synthesis, thus, it was used for docking to study the interaction of the investigated class of compounds with the T7pol active site.

The key non-covalent intermolecular relations of different types were determined for the ligand-receptor complex. The experimental data regarding the biological activity of the synthesized compounds are in sufficient agreement with the results of virtual screening [21].

Two methods of obtaining tricyclic analogues of nucleosides with triazine fragment were elaborated. The triazine-containing tricyclic bases were modified by direct glycosylation of peracyl-derivative of sugar in con- 


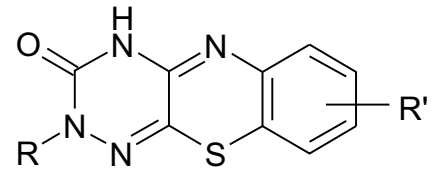

plication of DNA in vitro, one can assume that the mechanism of antiviral activity of the compounds may be based on inhibiting the functioning of transcriptional and replicative complexes.

Inhibitory properties of triazine-benzothiazine derivatives (TBT) in enzymatic and viral-cellular model systems

\begin{tabular}{|c|c|c|c|c|}
\hline Compound & $\begin{array}{l}\text { Transcription test-systems } \\
\text { T7pol, IC }{ }_{90}, \mu \mathrm{M}\end{array}$ & $\begin{array}{l}\text { PCR test-systems, } \\
\mathrm{IC}_{90}, \mu \mathrm{M}\end{array}$ & $\begin{array}{l}\text { HSV-2 ( } \mathrm{BH}) \text { in cell culture } \\
\text { RK-13, EC } \mathrm{C}_{50}, \mu \mathrm{M}\end{array}$ & $\begin{array}{l}\text { EBV in cell culture Raji, } \\
\qquad \mathrm{EC}_{50}, \mu \mathrm{M}\end{array}$ \\
\hline 3-охо-ТВТ & 100 & $>100$ & 2,7 & 4,6 \\
\hline 3-oxo-TBT (Rib) & 85,7 & 57,0 & 3,14 & 2,7 \\
\hline 3-oxo-TBT (Rib) & 89,0 & $\mathrm{~N}$ & 4,5 & 2,8 \\
\hline 3-охо-TBT (7-Cl) & 99,0 & 99,0 & 12,5 & $\mathrm{~N}$ \\
\hline 3-охо-ТВТ (8-Bu) & 22,5 & 75,0 & 15,9 & $\mathrm{~N}$ \\
\hline 3-oxo-TBT (7- $\left.\mathrm{CF}_{3}\right)$ & 87,4 & 87,0 & 7,0 & $\mathrm{~N}$ \\
\hline 3-охо-TBT (Rib, 7-CF ${ }_{3}$ ) & 71,7 & 47,8 & 3,9 & $\mathrm{~N}$ \\
\hline
\end{tabular}

$\mathrm{N}$ o t e. 3-oxo-TBT (core base) - 3-oxo-1,2,4-triazine[5,6-b][1,4]benzothiazine; Rib - N2-ribofuranoside; N - don't investigated.

ditions of the simplified version of «silyl condensation» method. Another way is the formation of tricyclic heterobase with fixed location of the sugar residue, taking into account corresponding triazine nucleosides, where the heterocycle is finished completely. This was the way to confirm the region-specificity of the glycosylation reaction as well as to reveal the dependence of the synthesis efficiency on the nature of benzene ring substitutes (method 1) or the substitutes of ortho-aminothiophenol - the initial compound in the annelation reaction (method 2) [20-21].

There was the in vitro investigation of the activity of tricyclic bases and their glycosides in the enzymatic testsystems and the impact of compounds on the reproduction of viruses of Herpes viridae family - herpex simplex virus, type 2 (HSV-2) and Epstein-Barr virus (EBV) (Table) [22, 23].

The investigation of triazine-benzothiazines in cell cultures, infected with herpes-viruses (HSV-2 and EBV), demonstrated that all substances are capable of efficient inhibition of the reproduction of both viruses with $\mathrm{EC}_{50}$ in the range of 2.7-15.9 $\mu \mathrm{M}$. Here the antiviral properties of glycoside derivatives of tricyclic bases (N2-ribofuranosides) were stronger that the properties of the bases [20]. Taking into consideration that TBT derivatives are also inhibitors of transcription and re-
All the previously considered condensed heterocyclic compounds are built on the basis of linear tricyclic systems (phenazine, acridine, triazine-benzothiazine). However, the obtaining and investigation of compounds with other molecular structures were of interest as well. The inhibitors, active regarding the enzymes of the system of nucleic acid biosynthesis, are known to contain specific «banana»- or $S$-like polycyclic structural fragments.

Based on this fact, we obtained about 30 arylidene derivatives of $[1,3]$ tiazole[3,2-a]benzimidazole-3 (2H)one(benzimidazothiazolone) - BT series compounds (7). The convenient method of synthesizing such substances was developed on the basis of the condensation of aromatic aldehydes with benzimidazothiazolone in the sodium acetate - acetic acid system.

It is noteworthy that despite the general structure of arylidene BT derivatives was confirmed by NMR and mass spectrometry, there was no unified view on the spatial configuration of molecules of these compounds. The quantum-chemical calculations of the transitory state of the reaction of forming BT compounds were used to demonstrate that cys-isomer should be realized in all cases. The X-ray structural analysis of BT derivatives confirmed their cys-configuration regarding the double bond in arylidene fragment of the molecule. 
BT derivatives demonstrated the highest inhibitory activity among the investigated compounds in the testsystem of in vitro transcription. The level of activity depends on the nature of the substitute in the arylidene fragment. For three substances the value of $\mathrm{IC}_{50}$ in the T7pol system is close to $10 \mu \mathrm{M}$, while for BT-29 substance, containing a dihydroxyphenyl fragment, it is $1.6 \mu \mathrm{M}$. In the concentration of $0.7 \mu \mathrm{g} / \mathrm{ml}(2 \mu \mathrm{M})$, this inhibitor ensures almost absolute inhibition of RNA synthesis. At the same time, the investigation of the impact of BT series compounds on the activity of topoisomerase I of Escherichia coli in the system of DNA relaxation in vitro did not reveal their inhibitory effect in the concentration of $50-100 \mu \mathrm{M}$.

The biological investigations of benzimidazole using the models of pathogenic bacterial (gram-positive aurococcus Staphylococcus aureus, gram-negative blue pus bacillus Pseudomonas aeruginosa) and fungal (C. albicans) infections did not reveal any compounds with the antimicrobial or antifungal activity. However, the significant anti-herpetic activity was revealed in the virus-cell system (the culture of continuous BHK cells) for a number of BT derivatives with a hydroxylor dimethylaminogroup in the phenyl nucleus. The MIC value for four compounds was in the range of 1.6-3.6 $\mu \mathrm{M}$, and the selectivity index - in the range of 90-250. At the same time some derivatives of BT series with $\mathrm{OH}$ - and $\mathrm{Et}_{2} \mathrm{~N}$-substitutes in the arylidene fragment, remarkable for the highest inhibitory activity in the transcription system, demonstrated a significant antiproliferative activity in vitro in the cultures of tumor HeLa cells $\left(\mathrm{EC}_{50} 1.1-2.9 \mu \mathrm{M}\right)$ and MCF-7 (human breast carcinoma, $\left.\mathrm{EC}_{50} 0.9-1.6 \mu \mathrm{M}\right)$.

Conclusions. Since the very establishment of the Department of Synthetic Bioregulators the main focus area has been the elaboration of new approaches to the creation of polynucleate nitrogen-containing systems regulators of functional activity of the enzymes, maintaining the biosynthesis of nucleic acids. The quantumchemical calculations, computational simulation of the structures of ligands and their complexes with targets allowed modeling several series of biologically active compounds on the basis of condensed 1,2,4-triazine, $\mathrm{N}$-substituted amides of triazinyl-6-propane carboxylic acid, $\mathrm{N}$-arylamides of phenazine-1-carboxylic acids, Nhetarylamides of acridone-4-carboxylic acid and arylide- ne-substituted benzimidazothiazolones. The simulated test-systems of transcription, and, partially, replication and relaxation of DNA were used for initial screening the synthesized compounds in vitro. The selection of these systems seems to be reasonable, because the mentioned biological processes are the principal targets of antimicrobial, antiviral and antitumor therapy. A targeted selection of new substances with subsequent investigation on the cellular level allowed revealing at least $3-$ 4 leader compounds in each obtained series, which are promising for further study and structural optimization. The abovementioned results of investigations were used for three $\mathrm{PhD}$ theses, 50 publications, 5 patents and numerous reports at national and international scientific forums.

\section{I. В. Алексєєва, А. Д. Швед}

Синтез і дослідження біологічної активності азотовмісних гетероциклічних сполук - регуляторів ферментів біосинтезу нуклеїнових кислот

Резюме

Узагальнено результати досліджень щодо створення нових регуляторів функціональної активності ферментів біосинтезу нуклеїнових кислот на основі полічиклічних азотовмісних гетеросистем. Комп'ютерний дизайн і молекулярний докінг у каталітичний сайт ферменту-мішені (Т7пол) дозволили провести спрямовану оптимізаиію базових структур. Отримано декілька серій сполук, з-поміж яких виявлено ефективні інгібітори вірусів родини герпесу (ВПГ-2, вірус Епштейна-Барр), грипу А та гепатиту С, а також препарати з потужною протипухлинною, протибактерійною та протифунгальною дією. Визначено перспективність застосування модельних тест-систем на основі ферментів, що обслуговують синтез нуклеїнових кислот, для первинного скринінгу потенційних інгібіторів in vitro.

Ключові слова: 6-азацичтидин, нуклеозиди аs-триазина, акридони, феназини, бензімідазотіазолони, інгібітори.

\section{И. В. Алексеева, А. Д. Швед}

Синтез и изучение биологической активности азотсодержащих гетероциклических соединений регуляторов ферментов биосинтеза нуклеиновых кислот

Резюме

Обобщены результаты исследований по созданию новых регуляторов функииональной активности ферментов биосинтеза нуклеиновых кислот на основе полициклических азотосодержащих гетеросистем. Компьютерный дизайн и молекулярный докинг в каталиический сайт фермента-мишени (Т7пол) позволили провести направленную оптимизацию базовых структур. Получено несколько серий соединений, среди которых выявлены эффективные ингибиторы вирусов семейства герпеса (ВПГ-2, вирус Эпитейна-Барр), гриппа А и гепатита $C$, а также препараты смощным противоопухолевым, антибактериальным и антифунгальным действием. Определена перспективность применения мо- 
дельных тест-систем на основе ферментов, обслуживающих синтез нуклеиновых кислот, для первичного скрининга потенциальных ингибиторов іп vitro.

Ключевые слова: 6-азацитидин, нуклеозиды аs-триазина, акридоны, фенезины, бензимидазотиазолоны, ингибиторы.

\section{REFERENCES}

1. Alexeeva I., Dyachenko N., Nosach L., Zhovnovataya V., Rybalko S., Lozitskaya R. et al. 6-Azacytidine - compound with wide spectrum of antiviral activity // Nucleosides Nucleotides Nucleic Acids.-2001.-20, N 4-7.-P. 1147-1152.

2. Zarubaev V. V., Slita A. V., Sukhinin V. P., Nosach L. N., Dyachenko N. S., Povnitsa O. Y. et al. Effect of 6-azacytidine on the course of experimental adenoviral infection in newborn Syrian hamsters // J. Chemother.-2007.-19, N 1.-P. 44-51.

3. Zarubaev V. V., Garshinina A. V., Kalinina N. A., Shtro A. A., Belyaevskaya S. V., SlitaA. V. et al. Activity of ingavirin (6-[2(1H-imidazol-4-yl)ethylamino]-5-oxo-hexanoic acid) against human respiratory viruses in vivo experiments // Pharmaceuticals.-2011.-4, N 12.-P. 1518-1534.

4. Dyachenko N., Alexeeva I., Nosach L., Shalamay A., Rybalko S., Palchikovskaya L. et al. The spectrum of antiviral activity of 6azacytidine, which have the prospect for drug development // Int. Conf. «New technologies of obtaining and application of biologically active substances» (Alushta, Crimea, Ukraine; May, 20-25 2002): Abstracts book.-Alushta, 2002.-P. 145-146.

5. Dyachenko N. S., Rybalko S. L., Nosach L. N., Alexeeva I. V., Shalamay A. S. Antiadenoviral and anti-herpes activity of 6-azacytidine // $12^{\text {th }}$ Int. Conf. on Antiviral Research (ICAR-99) (Jerusalem, Israel, March 1999): AB.-Jerusalem, 1999.-P 87.

6. Nosach L. N., Dyachenko N. S., Shalamay A. S., Alekseeva I. V., Kushko L. Ya., Ozvinchuk I. I. et al. Antiadenovirus and immunostimulating action of 6-azacytidine // Biopolym. Cell.-1996.12, N 1.-P. 75-85.

7. Alexeeva I. V., Palchikovskaya L. I., Nosach L. N., Usenko L. S., Zhovnovataya V. L., Dyachenko N. S. The glycosilic analogues of 6-azacytidine: synthesis and antiviral activity // Biopolym. Cell.-2004.-20, N 5.-P. 435-439

8. Alexeeva I., Palchykovskaya L., Shalamay A., Nosach L., Zhovnovataya $V$., Povnitsa $O$. et al. N4-amino-acid derivatives of 6azacytidine: structure-activity relationship // Acta Biochim. Pol.2000.-47, N 1.-P. 95-101.

9. Kostina V. G., Alexeeva I. V., Palchykovskaya L. I. Synthesis of novel 2',3'-dideoxy-6-azacytidine derivatives - potential retroviral reproduction inhibitors // Biopolym. Cell.-2001.-17, N 6.P. 560-564.

10. Dyachenko N. S., Nosach L. N., Povnitsa O. Y., Kuz'min V. E., Artemenko A. G., Lozitskaya R. N. et al. Structure-antiadenoviral activity of nitrogen containing macroheterocycles and their analogues // Mikrobiol. Z.-2006.-68, N 5.-P. 69-80.

11. Zagorodnaya S. D., Nesterova N. V., Golovan'A. V., Alexeeva I. V., Palchykovskaya L. I., Baranova G. V. AntiEBV activity of 6-azacytidine and its derivatives // Mikrobiol. Z.-2011.-73, N 6.-P. 41-49.

12. Palchikovs'ka L. G., GarmanchoukL.V., Alexeeva I. V., Usenko L. S., Shestakova T. S., Solyanik G. I. et al. The N1-glycosilic analogues of 6-aza-cytidine. Cytotoxic effect and influence on transcription in vitro // Biopolym. Cell.-2005.-21, N 5.-P. 433-439.
13. Platonov M. O., Sudakov O. O., Palchykovska L. G., Alexeeva I. V., Boyko Yu. V., Hovorun D. M. Nonempirical quantum-chemical conformational analysis of 6-azacytidine, a modified nucleoside with a wide spectrum of biological activities // Dopovidi NAN Ukrainy.-2004.-N 3.-P. 163-169.

14. Palchykovs 'ka L. H., Platonov M. O., Alexeeva I. V., Shved A. D. Composite bioregulators on the base of phenazine-1-carboxylic acid and 6-azauracil derivatives. Synthesis and structural characteristics // Biopolym. Cell.-2003.-19, N 3.-P. 281-286.

15. Alexeeva I. V., Palchykovska L. G., Kostina V. G., Platonov M. O., Pavlenko L. V., Lysenko N. A. et al. Search for novel antifungal compounds among arylamides of 1,2,4-triazinyl-6-propanecarboxylic acid // Biopolym. Cell.-2007.-23, N 5.-P. 441-448.

16. Kostina V. G., Alexeeva I. V., Lysenko N. A., Grigorjeva S. M., Egorov D. P., Rybalko S. L. et al. Novel derivatives of 3-[3,5-dioxo-1,2,4,5-tetrahydro-1,2,4-triazinyl-6]-propionic acid: synthesis and antifungal effect// Ukr. Bioorg. Acta.-2012.-10, N 1.P. 3-8.

17. De Logu A., Palchykovska L. H., Kostina V. H., Sanna A., Meleddu R., Chisu L. et al. Novel N-aryl- and N-heteryl phenazine-1carboxamides as potential agents for the treatment of infections sustained by drug-resistant and multidrug-resistant Mycobacterium tuberculosis // Int. J. Antimicrob. Agents.-2009.-33, N 3.P. 223-229.

18. Palchykovs'ka L. H., Alexeeva I. V., Kostina V. H., Platonov M. O., Negruts 'ka V. V., Deriabin O. M. et Al. New amides of phenazine-1-carboxylic acid: antimicrobial activity and structure-activity relationship // Ukr. Biokhim. Zh.-2008.-80, N 3.-P. 140-147.

19. Stankiewicz-Drogon A., Palchykovska L. G., Kostina V.G., Alexeeva I. V., Shved A. D., Boguszewska-Chachulska A. M. New acridone-4-carboxylic acid derivatives as potential inhibitors of Hepatitis C virus infection // Bioorg. Med. Chem.-2008.-16, N 19.-P. 8846-8852.

20. Alexeeva I. V., Palchykovska L. G., Usenko L. S., Kostina V. G. Tricyclic 1,2,4-triazine bearing heterosystem: directed synthesis of new bioactive compounds // Biopolym. Cell.-2008.-24, N 5.P. 406-411.

21. Palchykovska L. G., Alexeeva I. V., Platonov M. O., Kostenko O. M., Usenko L. S., Negrutska V. V. et al. New 1,2,4-triazine bearing compounds: molecular modeling, synthesis and biotesting // Biopolym. Cell.-2009.-25, N 6.-P. 491-499.

22. Golovan A. V., Nesterova N. V., Zagorodnya S. D., Alexeeva I. V., Palchykovskaya L. I., Usenko L. S. et al. Inhibitors of EpsteinBarr virus reproduction - ribonucleosides of 3-substituted 1,2,4triazino-[5,6-b]-[1,4]benzothiazines // Mikrobiol. Z.-2010.72, N 2.-P. 36-42.

23. Palchykovska L. G., Rybalko S. L., Rymar S. Yu., Starosyla D. B., Alexeeva I. V., Shved A. D. Use of the model DNA-containing enzyme systems to search for inhibitors of nucleic acid synthesis in viruses and bacteria // Laboratory Diagnostics.-2010.-N 3 (53).-P. 31-37.

24. Palchykovska L. G., Alexeeva I. V., Negrutska V. V., Kostyuk Yu. K., Indychenko T. M., Kostenko O. M. et al. Inhibition of in vitro transcription by 2-arylidene derivatives of thiazolo[3,2- $\alpha]$ benzimidazol-3(2H)-one // Biopolym. Cell.-2010.-26, N 6.P. 508-511. 